\title{
PENYULUHAN HUKUM HAK- HAK TERSANGKA TERKAIT BANTUAN HUKUM DI RUMAH TAHANAN WANITA PONDOK BAMBU JAKARTA TIMUR
}

\author{
Fransiska Novita Eleanora ${ }^{1 *}$, Andang Sari ${ }^{2}$ \\ ${ }^{1}$ Fakultas Hukum, Universitas Bhayangkara Jakarta Raya \\ Jln. Perjuangan No. 81 Bekasi Utara, Jawa Barat 17143 \\ ${ }^{2}$ Fakultas Hukum, Universitas Bhayangkara Jakarta Raya \\ Jln. Perjuangan No. 81 Bekasi Utara, Jawa Barat 17143 \\ *Email: siska_ita@yahoo.com
}

\begin{abstract}
Abstrak
Pengakuan dan perlindungan akan hak hak manusia sudah ada sejak dilahirkan ke dunia, termasuk juga haknya sebagai tersangka dan secara cuma-cuma untuk mendapatkan akan bantuan terhadap hukum dan pendampingan terhadap kejahatan yang dilakukan. Terkait bantuan hukum seperti pengaturan dalam pidana dan ketentuan akan hukum acaranya dalam suatu kitab bahwa ternyata masih banyak masyarakat ataupun tersangka yang sama sekali tidak mengetahuinya, bagaimana prosedur dan cara yang ditempuh untuk memperolehnya. Penyuluhan hukum di rumah tahanan wanita yang berlokasi di pondok bambu wilayah jakarta timur ini bertujuan memberikan pemahaman dan pengetahuan dari tersangka kaum wanita mengenai hak haknya sebagai warganegara dan diperlakukan secara adil, didapatkan juga secara berkeadilan terhadap hukum yang mempunyai kepastian dan adanya juga suatu yang yang memang sama yakni perlakuan akan adanya hukum tanpa adanya pengecualian baik bagi masyarakat mampu atau tidak mampu (miskin).
\end{abstract}

Kata kunci : bantuan hukum, hak, keadilan

\section{PENDAHULUAN}

Negara yang sangat berlandaskan akan hukum adalah Indonesia dan jelas sangat menghormati dan menghargai pengakuan, perlindungan dan terjaminnya keberadaan hak-hak asasi manusia sudah diakui oleh Negara, termasuk juga hak-hak tersangka. Hak hak tersebut tertuang akan adanya suatu ketentuan pidana dalam suatu kitab akan adanya undang-undang tentang hukum dan acaranya atau disebut juga Tahun 1981 dengan Nomor 8 lebih tepatnya adalah UndangUndang, dimana angka 14 pasal 1 tersebut menjelaskan berdasarkan adanya bukti permulaan karena adanya perbuatan dan keadaannya disebut sebagai pelaku dari tindak pidana yang terjadi. Perlindungan diberikan kepada seluruh warga masyarakat karena kewajiban Negara untuk melindungi segenap banga tanpa adanya pengecualian karena menyangkut akan Tumpah dan darah dari Indonesia yang tercinta.

Penerapan secara luas dapat diartkan bahwa siapapun atau setiap orang mendapatkan atau berhak atas kepastian hukum, jaminan, dan pengakuan yang adil serta mendapat akan hukum khususnya perlakuan tanpa pilih dan kasih artinya semuanya sama, termasuk juga dalam hal ini masyarakat dalam kategori mampu atau tidak mampu (miskin), karena semuanya berhak akan hakhaknya untuk dilindungi namun, tidak semuanya memahami hal tersebut dikarenakan buta hukum dan tidak mengetahui bagaimana prosedurnya serta jalur yang ditempuh untuk mendapatkan haknya.

Bantuan hukum yang diberikan yakni dengan mendampingi masyarakat miskin terkait akan keberadaan hak-haknya, dalam arti jika masyarakat yang dianggap bermasalah dengan hukum memiliki beberapa ketentuan yaitu : (i) jika mampu tidak jadi masalah dianggap bisa atau dapat menunjuk advokatnya, (ii) sedangkan tidak mampu tentu menjadi masalah (tidak bisa menunjuk 
advokat) hal inilah menjadi kewajiban untuk memberikan pendampingan hak-haknya, dengan kata lain bahwa yang tidak mampu tersebut harus diberikan bantuan hukum secara cuma-cuma.

Penyuluhan hukum ini dilaksanakan dengan menitikberatkan kepada terwujudnya keadilan berdasarkan adanya Tahun 2011 dengan Nomor ke-16 ketentuan dari suatu undang-undang atau peraturan dari Negara mengenai organisasi bantuan hukum yang dikhususkan gratis kepada masyarakat yang kurang mampu, dan diberikan baik pada tersangka (di kepolisian) maupun terdakwa (di persidangan), bantuan hukum berupa pendampingan disediakannya di setiap perguruan tinggi lembaga konsultasi bantuan hukum (LKBH).

Perlindungan akan hak konstitusional ini juga berhubungan dengan adanya suatu Surat berisikan Edaran dari Mahkamah yang Agung (SEMA) sebagai puncak tertinggi dalam suatu peradilan Tahun 2010 Nomor 10 pasal yang ke 27 dengan jelas menyebutkan bahwa mereka dianggap yang memang sangat berhak untuk menerima atau mendapatkan akan adanya jasa atau berbentuk pos dari suatu bantuan hukum adalah yang mereka dianggap memang tidak dapat atau tidak mampu membayar akan adanya jasa dari advokat termasuk anak dan perempuan beserta penyandang disabilitas seusai dengan pemberlakuan adanya peraturan yang berupa perundangan.

Hasil temuan yang didapatkan tidak semua tersangka wanita mengetahui akan adanya bantuan hukum, disampimg mereka juga buta hukum dengan segala keterbatasan ilmu pengetahuan, sehingga kurang dan memang ketidaktahuan mereka atau tidak memahami dan mengerti maksud bantuan hukum tersebut.

Syarat dan adanya ketentuan yang benar-benar harus dan selalu dipenuhi untuk mendapatkan secara adanya cuma-cuma terhadap hukum dan prosedur bantuannya diantaranya, (a) Fotokopi Kartu Tanda Penduduk (KTP), (b) Surat Keterangan Miskin (SKTM) dari Lurah atau dari Kecamatan sesuai dengan domisili dari pemohon yang mengajukan bantuan hukum, (c) uraian mengenai persoalan dari pemohon bantuan hukum tersebut, (d) dan juga surat kuasa, SKTM dapat juga diperoleh masyarakat dari kepolisian, kejaksaan negeri, rumah tahanan, lembaga pemasyarakatan dan pengadilan negeri.

\section{METODE}

Kegiatan ini diikuti oleh Mahasiswa Semester 4 dan 6 yang sudah mengikuti atau mengambil mata kuliah Hukum Acara Pidana dalam kaitannya dengan tugas dan fungsi advokat, serta diikuti sekitar 25 tersangka wanita, menmbagikan dan mengisi form kepada peserta mengenai identitas diri dan kejahatan yang dilakukan. Keterlibatan mahasiswa disini agar namtinya kelak dapat mengetahui pemberian bantuan hukum gratis kepada yang memang tidak mampu yakni masyarakat, sebagai advokat atau kuasa hukum, dalam melaksanakan kegiatan dari penyuluhan hukum ini yakni, (i) Presentasi dengan memaparkan materi terkait akan keberadaan hak dari tersangka, (ii) Tanya Jawab, dimana para peserta yaitu tersangka wanita bertanya mengenai hakhak yang mereka dapatkan sebagai tahanan di pondok bambu tersebut.

\section{HASIL DAN PEMBAHASAN}

Hasil

\begin{tabular}{|c|l|l|l|}
\hline No & \multicolumn{1}{|c|}{ Unsur } & \multicolumn{1}{|c|}{ Pra Pengabdian } & \multicolumn{2}{c|}{ Pasca Pengabdian } \\
\hline 1 & $\begin{array}{l}\text { Hak Terkait terhadap adanya } \\
\text { Bantuan dan prosedur Hukum } \\
\text { secara gratis atau prodeo } \\
\text { (cuma-cuma) dalam Proses } \\
\text { Peradilan }\end{array}$ & $\begin{array}{l}\text { Tidak mengetahui mengenai } \\
\text { adanya secara gratis atau } \\
\text { cuma-cuma akan keberadaan } \\
\text { hukum dan bantuanna }\end{array}$ & $\begin{array}{l}\text { Mengetahui } \\
\text { Memahami adanya bantuan } \\
\text { hukum yang diberikan } \\
\text { kepada mereka dalam } \\
\text { kategori dianggap tidak } \\
\text { atau miskin atau tidak } \\
\text { punya kemampuan untuk } \\
\text { membayar terhadap kuasa } \\
\text { hukumnya }\end{array}$ \\
\hline 2 & $\begin{array}{l}\text { Bantuan Hukum Diatur Dalam } \\
\text { KUHAP }\end{array}$ & $\begin{array}{l}\text { Tidak Mengetahui Aturan } \\
\text { tersebut. }\end{array}$ & $\begin{array}{l}\text { Sudah Memahami Bantuan } \\
\text { Hukum Disertai Dasar } \\
\text { Hukum }\end{array}$ \\
\hline
\end{tabular}


Pembahasan

Hasil diatas menunjukkan sebelum pra pengabdian tidak mengetahui hak hak terkait akan bantuan hukum, dan tidak mengetahui atau memahami bahwa bantuan hukum yang diberikan bagi mereka yang termasuk orang yang benar-benar tidak mempunyai kemampuan dalam suatu peradilan diatur dalam peraturan perundang-undangan, tetapi setelah dilakukannya penyuluhan hukum maka perlahan-lahan dan pasti akhirnya mengetahui bahwa ada bantuan hukum yang diprioritaskan bagi mereka yang memang miskin dan tidak berdaya untuk membela kepentingan akan hak-haknya serta menjungjung tinggi akan pemerataan yang berbasiskan keadilan dan persamaan hak serta adanya supremasi hukum.

Setiap peserta (tersangka wanita) dikumpulkan dan dilakukan dialog satu persatu untuk didengarkan kronologis dari peristiwa yang dilakukannya, penyebab sampai melakukan kejahatan, dan ancaman hukuman atau sanksi yang nantinya akan diterima, dan berapa lama
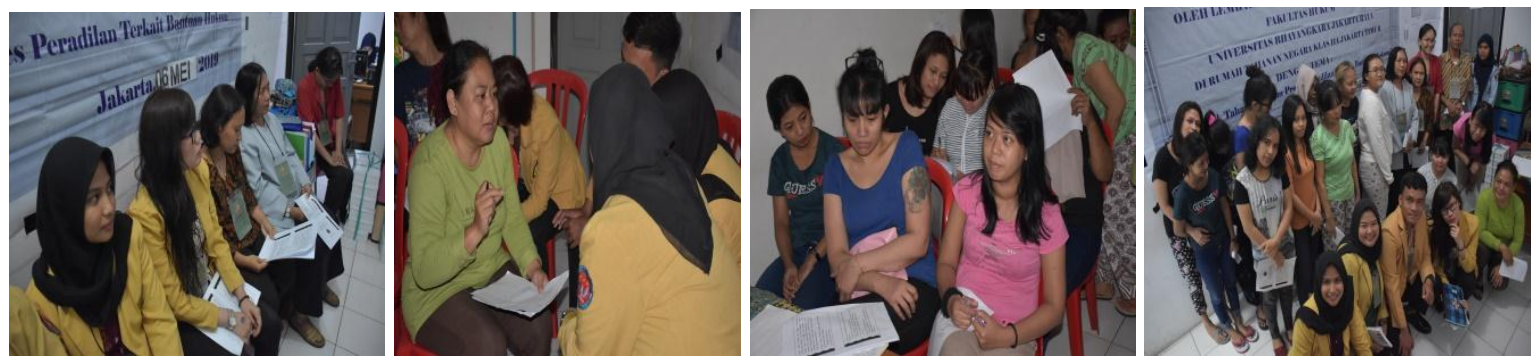

\section{Gambar 1. Dialog dengan para Peserta}

Hukuman yang akan dijatuhkan, sesuai pasal-pasal yang ada didalam suatu Ketentuan akan peraturan Undang-Undang yakni Pidana dan hukumnya serta adanya sanksinya (KUHP), sehingga perlu didampingi oleh kuasa hukumnya adanya jasa advokat, dengan mencantumkan syarat-syarat seperti yang telah disebutkan diatas. Bantuan hukum didalam Hukum yang berisi ketentuan terhadap pidana dan acaranya dalam satu Kitab atau disingkat dengan (KUHAP) diatur dalam Pasal 54 KUHAP, bahwa guna kepentingan pembelaan tersangka/terdakwa berhak mendapatkan bantuan hukum baik dari seseorang atau lebih dari penasihat hukum dari tingkat pemeriksaan/penyidikan hukumnya menurut tatacara yang diatur oleh undang-undang, sedangkan dalam Tahun 2003 dengan Nomor 18 dalam ketentuan Undang-Undang ayat 1 pasal 22 disebutkan Mereka yang dianggap tidak mampu untuk mendapatkan keadilan merupakan tugas dari Advokat ataupun kewajibannya memberikan secara gartis atau cuma-cuma akan bantuannya terhadap hukum.

Persyaratan yang sangat mudah tersebut dapat disanpaikan dalam surat permohonan kepada Direktur Organisasi Bnatuan Hukum yang akan ditindaklanjuti dalam waktu 3 (tiga) hari, apakah ditolak atau diterima permohonannya, jika ditolak akan diberikan alasannya.

\section{KESIMPULAN}

Hak-Hak Tersangka dalam memperoleh bantuan hukum merupakan jaminan dan perlindungan terhadap adanya pengakuan hak asasinya yang berasaskan pada keadilan memperoleh haknya, pemerataan tanpa adanya diskriminasi dan kepastian hukum, karena hal tersebut sudah diakui oleh Negara, dan tercantum di dalam Ketentuan Tahun 1981 Nomor 8 yakni UndangUndang mengenai Hukum Acara dan Pidana dalam Kitabnya, Tahun ke 2003 dengan Nomor 18 berbentuk suatu Undang-Undang yang berisikan tentang Advokat dan Surat mengenai Edaran dari Mahkamah Agung (SEMA) dengan Tahun yang 2010 dengan Nomor 10 yang memuat tentang suatu Pedoman Mengenai Adanya Pemberian Akan Prosedur Bantuan dan hukum

Pemberian bantuan hukum kepada masyarakat yang tidak mampu, merupakan peran serta Negara untuk melindungi warganya, dimana dalam pelaksanaannya masih kurang dan terbatasnya advokat yang ada, sehingga diperlukan banyak advokat dalam penanganannya dengan moralitas, integritas dan juga kurangnya pemahaman serta kepercayaan masyarakat terhadap bantuan hukum yang ada, diperlukan adanya sosialisasi yang mendalam terkait pelaksanaannya, serta masih minimnya organisasi yang memberikan bantuan hukum kepada masyarakat miskin, seharusnya di 
setiap propinsi agar masyarakat mendapatkan akses cepat terhadap bantuan hukum yang berkeadilan.

\section{DAFTAR PUSTAKA}

Andi Hamzah, (2012) Hukum Acara Pidana Indonesia, Cetakan ke-6, Sinar Grafika, Jakarta.

Munir Fuady, (2016) Hak Asasi Tersangka Pidana, Prenada Media Group, Jakarta

Heidy Visilia Sahanggamu, Hak Tersangka Untuk Mendapatkan Bantuan Hukum Dalam Proses Penyidikan Perkara Pidana, Lex Crimen, Vol. II/ No. 2/April-Juni/2013, Jurnal Elektronik Bagian Hukum Pidana Fakultas Hukum Universitas Sam Ratulangi Manado, diakses, Sabtu, 01 Juni 2019, Jam, 11.03 https://ejournal.unsrat.ac.id/index.php/lexcrimen/issue/archive wib hal. 162

Undang-Undang Nomor 8 Tahun 1981 Tentang Kitab Undang-Undang Hukum Acara Pidana (KUHAP)

Undang-Undang Nomor 18 Tahun 2003 Tentang Advokat

Undang-Undang Nomor 16 Tahun 2011Tentang Bantuan Hukum

Surat Edaran Mahkamah Agung (SEMA) Nomor 10 Tahun 2010 Tentag Pedoman Pemberian Bantuan Hukum 